\title{
APPLICATION OF THE METAPHOR APPROACH IN GERMAN LEARNING AT SMA NEGERI 7 AMBON
}

\author{
Patresia S. Apituley ${ }^{1}$, Carolina Lestuny ${ }^{2}$ and Piet Soumokil ${ }^{3}$ \\ Pattimura University, German Language Education Study Program ${ }^{123}$
}

Email: c.lestuny14@gmail.com

\begin{abstract}
The purpose of this study 1) To determine the impact of applying metaphors on learning German. 2) To Improve and optimize the role of the teacher's metaphor in learning German. The population in this study were all students of SMA Negeri 7 Ambon, while the selected samples were students grade 10 of SMA Negeri 7 Ambon. The results of the dependent ttest calculation showed that the $\mathrm{t}$-value is more than the $\mathrm{t}$-table ( $\mathrm{t}$-value $11.30>$ t-table 1.72913). The results of these calculations indicated that there was a significant difference between German learning's outcomes before and after treatment with the application of metaphors. Thus, it can be said that application of metaphor had a positive impact and can effectively assist students in learning German and increase learning outcomes of students.
\end{abstract}

Keywords: Metaphor, German Learning Outcomes

\section{Introduction}

Deutsch als Fremdsprache (DAF) is the study of German as a foreign language. German language learning be taught at senior high school / vocational level from first to third grade and at the university. In this global era, $D A F$ learning has developed rapidly because apart from German being the most frequently used language in the European Union, Germany is a country as a choice for both continuing education and working. This is certainly a challenge for German language educators to develop creative and innovative learning. Besides aiming to increase German language enthusiasts, it also produces qualified graduates in their fields.

However, based on UKG in 2012 data measured in terms of professionalism and pedagogy, it can be seen that the competence of German language teachers in Maluku is at an average score of 33.27 out of a score of 100. As for the Ambon City area itself, the competence of German language teachers is at an average score of 35. ,23 (Ratumanan 2013). This information shows that the competence of German language teachers is lower and certainly greatly affects the learning outcomes of German and students' language skills. In relation to learning German in SMA in Ambon City, especially at SMA Negeri 7, it is known that teacher competence can be categorized as good. This is based on the level of German language skills of SMA Negeri 7 Ambon teachers who on average have a language skills certificate of B1 level. So it can be concluded that high school teachers already have good pedagogic competence. However, an educator needs to understand and apply the teacher's metaphor (Metapher für den Lehrberuf) in the learning process. One teacher 
conceptualized her role of teacher as a saintly facilitator, a comedian, and a miser. (Tobin, 1990). As we all know that, there are several teacher metaphors that can be used in learning process, for example as a designer who make a learning implementation plan (RPP) and evaluation before teaching so that learning objectives can be achieved. In addition, the teacher can also act as a conductor. As a conductor, the teacher must be able to lead the teaching and learning process by managing all aspects needed during learning process, include some obstacles in the learning process in the classroom. Like a conductor in a musical orchestra that combines several types of instruments into a beautiful simphony. There are some teacher metaphors that need to be understood and applied in classroom learning. The application of the teacher's metaphor is strongly influenced by the learning objectives, the learning steps that have been prepared in the learning plan (RPP) and the classroom situation. So it can be concluded that in a teaching and learning process, several teacher metaphors can be applied.

Based on the observations, it is found that the teachers at SMA Negeri 7 Ambon have not fully understood the teacher's metaphor. One of the teacher's metaphorical roles that is often carried out is the teacher as a gardener. Just as a gardener plants seeds, waters them regularly and monitors them until the seeds grow, so a teacher who in the learning process more often transfers his knowledge to students as a whole. This certainly does not have a good impact on students' cognitive development and is not in line with the latest $21^{\text {st }}$ century learning methods. Students are expected to be able to analyze problems in learning and find the right solution, facilitated by the teacher.

\section{Metaphors for Educators}

Because German language is taught as a foreign language, the teacher as a Vermittler (distributor) must be able to use contemporary and varied methods, besides this which attracts students to choose German language as favorite subject, it also plays a role in being able to instill German language in students well, considering this language is the foreign language of the learners, after the class is over, most of them are no longer in touch with the language. Currently, there are various methods and learning strategies that are varied and interesting to be applied in DaF learning. One of the important strategies for educators to understand and master is Metaphors. In a paper presented at the Annual meeting of the American Educational Research Association Clarken ofdive Northern Michigan University introduced 5 metaphors for educators, but before weinto these 5 metaphors, we need to understand the meaning of the metaphors used in the paper presented by Clarken.

"Metaphor is a process of comparing and identifying one thing with another. Then, as we see what things have in common, we see the general meaning they have. Now, the ability to see the relation between one thing and another is almost a definition of intelligence. Thinking in metaphors (...) is a tool of intelligence. Perhaps it is the most important tool'. Hatcher in (Clarken, 1997) 
Metaphor is the process of comparing and identifying one thing with another. If we look at what they have in common, we see the general meaning they have. Today, the ability to see the relationship between one thing and another is almost the definition of intelligence. Thinking metaphorically is [...] a tool of intelligence. Perhaps it is the most important tool. (Clarken, 1997, p.3) also revealed that "language, as a vehicle to convey form and meaning to reality, constantly utilizes metaphors to explain reality by comparing one thing to something else. Some consider all language metaphorical". This means that language, which is understood as a tool to convey form and meaning to reality, constantly uses metaphors to explain reality by comparing one thing with another. It is also referred to as a figurative expression. Weaver in (Clarken 1997, p. 3) argues that figures of speech or figurative expressions, which are often described as indirect ways expressing meaning, are the most important part of diction. In the quote Weaver also reveals that some linguistic students argue that there are no truly literal/correct expressions, because language is basically metaphorical. He also added that metaphors can give us an explanation of the understanding and conception of each reality being compared. The four main functions of metaphor are (1) to give concreteness, (2) to clarify the unknown, (3) to express the subjective, and (4) to assist thought. Farrell (2007:86f) states that Besonders klar zeigen sich die Vorstellungen von Lehrkrafte, wenn man sie bittet, ihre Tätigkeit mit anderen Berufen zu vergleichen. Metaphern erleichtern den Zugang zu komplexen Erfahrungen und Situationen. Sie können Lehrenden deshalb beim Unterrichten eine Orientierung geben und ermoglichen es ihnen zu gleich, Ihre Denk-und Gefuhlsmuster bewusster wahrzunehmen.It means teachers' ideas become particularly clear when they are asked to compare their work with other professions. Metaphors facilitate access to complex experiences and situations. It can therefore give teachers orientation when teaching and at the same time enable them to be more aware of their thought and emotional patterns.

(Clarken, 1997, p.3) reveals that there are two basic principles of instruction, namely to go from the known to the unknown and to go from the concrete to the abstract. This can be done metaphorically by using concrete examples to explain abstract principles. A known, visible or physical reality will be used to help describe an unknown, invisible, or spiritual reality. Frequently limited vocabulary and understanding requires the use of comparisons to help someone in understanding one concept to another. (Clarken, 1997, p.4) also stated that most new teachers have spent many years as students observing and participating in activities with the teacher. Through these experiences they develop images, ideals, and models of a teacher. When students become teachers, they begin to reconstruct this knowledge based on their new experiences from the teacher's point of view. New teachers often work based on common beliefs, images or metaphors that can negatively affect their teaching. Two such common metaphors are "teacher as friend" and "teacher as strict authoritarian". Many new teachers have to learn through painful experiences that this approach generally doesn't work. Individual teaching metaphors cannot be separated. 
They must be in a dominant context or metaphor of what it is to teach students in education. Behind teaching metaphors there is a myth about school, such as school as a place to work.

Furthermore, according to Clarken (1997) "The teacher as authoritarian boss model is an extension of the school as a work place metaphor. If a teacher were to use the school as a learning place metaphor as opposed to the school at work place metaphor, one would expect the classroom and teaching to be arranged to facilitate learning as opposed to facilitating order and production. The organizational design and allocation of resources in the school would be different as would the relationship between the teacher and learner in these two metaphors. Some teachers see their role as a manager, dictator, or drill sergeant which puts the teacher in the active role and the students in the passive role as wish the teacher as a dispenser of knowledge". This means that the teacher acts as a leader who has full power in the classroom. This certainly affects the interaction between teachers and students. However, some teachers also play the role of managers, dictators and even soldiers who make teachers more active than students. Clarken (1997) further explained that, Sometimes the language is used to describe our belief and behavior is what we wish for or the ideal we hope to achieve, not of the real experience. The teacher may describe herself as a facilitator or a guide but may act as a director or dispenser. The teacher operating under the metaphor of the entertainer will behave differently than the teacher operating under the metaphor of the captain of the ship. A teacher may for one day or period operate using one metaphor and for another day or period used another. When the classes are uncooperative or unresponsive and must be directed and controlled, teachers often take the role of the demanding captain, leader, disciplinarian and task master. When the classes are more ideal, teachers can operate under more ideal metaphors. Because teaching is such a complex activity, teachers may find themselves operating under several metaphors at once. One teacher conceptualized her role of teacher as a saintly facilitator, a comedian, and a miser (Tobin, 1990). The saintly facilitator role applied only to the ideal class, which is what she thought teaching should be like. When she actually taught, she was in the role of comedian, entertaining the class. When that was not successful, she became a miser with her time and effort. This theory explains that teachers in the learning process need to understand and apply different metaphors. For example as a facilitator, director, captain, comedian and even entertainer. This teacher metaphor needs to be adapted to the learning objectives and the classroom situation and conditions so that the learning objectives can be achieved.

There are several types of metaphors that teachers can use:

\section{Teacher as Parents}

The roles and responsibilities of parents have served as a guide for teachers for many years. The legal principle in loco parentis (in the place of parents), is a guiding idea about the role of teachers - they act as parents to students, with equal rights, responsibilities and authority, while they are in school. 


\section{Teacher as Gardeners}

Almost everyone has experience with plants, even those who live in polar regions or deserts. This metaphorical image as a gardener is powerful, its simple language, its charm and elegance make it a useful tool. The teacher is like a gardener who is good at planting seeds, watering them, fertilizing and caring for them so that plants can grow to be big and bear fruit.

\section{German Learning Outcomes}

Generally learning outcomes means behavior change after learning process. Sjukur in Saminah, (2018) states Learning outcomes are abilities obtained by individuals after the learning process, which can provide behavioral changes in both knowledge, understanding, attitudes and skills of students so that they become better than before. German language is one of foreign language that learned at high school and vocational school. It consists of four language skills and structure. In essence, learning outcomes indicate the level of student ability in following a learning process. The level of student ability from this learning outcome can be seen from the cognitive, affective, and psychomotor aspects (Bloom in Purba, 2020: 17). In line with this opinion, Arikunto in Purba (2020:17) states that learning outcomes are something that is obtained from and after learning activities take place. Learning outcomes are expressed in the form of numbers, letters, or words good, moderate, and lacking. From the two opinions above, it can be stated that learning outcomes are student abilities whose indications are in the form of mastery of knowledge, changes in attitudes, and improvement of skills obtained after participating in learning activities. This learning outcome is an actual ability that can be measured directly through tests that are in accordance with learning objectives (Purba,dkk 2020:17)

\section{Method}

This research is an experimental study, where the experiment was only carried out on one group of students, without a comparison group. In this study, a metaphorical approach will be applied in learning German, which is expected to help teachers improve their German teaching skills.

\section{Population and Sample}

The population of this study were all students of SMA Negeri 7 Ambon, while the selected samples were grade 10 students of SMA Negeri 7 Ambon.

\section{Research Variables}

There are two variables that will be studied in this study, namely the dependent variable is German language learning and the independent variable is the metaphorical approach.

\section{Data Collection Techniques}

Data collection techniques used in the implementation of this research are: (1) Observation and interviews, as well as giving a questionnaire to obtain initial data about the situation or state of learning German language at SMA Negeri 7 Ambon without using a metaphorical approach (2) Applying a metaphorical approach in learning German and (3) Giving posttests and questionnaires to get an idea of the 
results of learning German, after the experiment was carried out, by applying a metaphorical approach.

\section{Research Result}

From the acquisition of German language learning test scores on the pre-test and post-test, it can be described as follows:

Tabel 1. Learning outcomes by applying Metaphor Approach

\begin{tabular}{|c|c|c|c|}
\hline No. & Subjct & Pre-test & Post-test \\
\hline 1. & Student 1 & 65 & 80 \\
\hline 2. & Student 2 & 70 & 90 \\
\hline 3. & Student 3 & 55 & 70 \\
\hline 4. & Student 4 & 50 & 65 \\
\hline 5. & Student a 5 & 45 & 60 \\
\hline 6. & Student 6 & 75 & 90 \\
\hline 7. & Student 7 & 75 & 85 \\
\hline 8. & Student 8 & 30 & 60 \\
\hline 9. & Student 9 & 60 & 75 \\
\hline 10. & Student 10 & 65 & 70 \\
\hline 11. & Student 11 & 55 & 60 \\
\hline 12. & Student 12 & 55 & 75 \\
\hline 13. & Student 13 & 50 & 75 \\
\hline 14. & Student 14 15 & 90 \\
\hline 15. & Student 15 16 & 65 \\
\hline 16. & Student 16 & 70 & 60 \\
\hline 17. & Student 17 18 & 40 & 75 \\
\hline 18. & Student 18 & 80 \\
\hline 19. & Student 19 & 45 & 75 \\
\hline 20. & Student 20 & 55 & 70 \\
\hline
\end{tabular}

From the German learning test scores, there were 20 respondents before being treated with the application of metaphors and it was known that the lowest score of 30 students was 1 person, while the highest score of 75 as many as 2 people from the maximum value of 100 .

The test scores for German learning outcomes for 20 respondents after being applied with metaphors and it is known that the lowest score of 60 students is 4 people, while the highest score is 90 as many as 3 people from the maximum value of 100. The calculation results describe $t_{\text {value }}=11.30$ when compared with $t_{\text {table }}$ at $a$ significant level $=0.05$ and degrees of freedom $=19$ then obtained $t_{\text {table }}=1.72913$. The results of these calculations show that there is a significant difference between the results of learning German before and after the application of the metaphor. German learning outcomes of students after treatment using metaphors were higher than before application. Thus, it can be said that the application of metaphors has a positive effect and if used in the German language learning process in schools, it will improve student learning outcomes. 


\section{Conclusion}

Based on the results of the study, it can be concluded that there is an effect of applying metaphors on the students of SMA Negeri 7 Ambon. Through the application of metaphors, among others, the teacher's role as manager, gardener, conductor and other forms of metaphor are very useful and can have a positive impact not only on children's learning outcomes as seen through test results, but also to make the classroom atmosphere better. With the metaphor, students are more motivated and enthusiastic in the teaching and learning process. This is proven by the dependent $\mathrm{t}-$ test formula where the number of $t_{\text {value }}=11.30>t_{\text {table }}$ at a significant level $=0.05$ and degrees of freedom $=19$. These results prove that the application of metaphors to German learning outcomes is effective to use.

\section{References}

Auswärtiges Amt. (2015). Deutsch als Fremdsprache weltweit. Datenerhebung 2015. Abgerufen am 10. Februar 2020 Von Goethe Institut : https://www.goethe.de/resources/ files/pdf37/Bro_Deutschlernerhebung_final2.pdf

Auswärtiges Amt. (2015). Deutsch als Fremdsprache weltweit. Datenerhebung 2015. Abgerufen am 10. Februar 2020 Von Goethe Institut : https://www. goethe.de/resources/files/pdf37/Bro_Deutschlernerhebung final2.pdf

Barkowski, H. (2010). Fachlexikon Deutsch als Fremd - und Zweitsprache. Tübingen/ Basel: Francke.

Clarken, R. H. (1997). Five Metaphors for Educators. American Educational Research Association. Chicago.

Europäische Union. (Februar 2006). Eurobarometer Spezial - Die Europäer und ihre Sprachen

Abgerufen am 10. Februar 2020 von https://ec.europa.eu/commfrontoffice/ publicopinion/archives/ebs/ebs_243_de.pdf

Farrell, Thomas (2007): Reflective Language Teaching. From Research to Practice. London: Continium

Götze, L., \& Gerhard Helbig, G.H. -J. (2010). Entwicklungslinien des Faches. Die Strukturdebatte als Teil der Fachgeschichte.

Purba,dkk (2020). Efektivitas Strategi pembelajaran problem based learning dan analisis gaya belajar terhadap hasil belajar Bahasa Jerman Mahasiswa Prodi pendidikan Bahasa Jerman FKIP Universitas HKBP Nommense http://repository.uhn.ac.id/bitstream/handle/123456789/3836/3.\%20 Laporan\%20Penelitian\%20(Apr\%202020).pdf.pdf? sequence $=1$

Schart M.\& Legutke M (2012). Lehrkompetenz und Unterrichtsgestaltung. Stuttgart: Klett

Suminah,dkk (2018): Peningkatan Hasil Belajar dan Motivasi Belajar Siswa melalui Pendekatan Behavior Modification.: Jurnal Kajian Teori dan Praktik Pendidikan, Vol 3, No 2 